\title{
Sustainability of Disability-Related Services in Canada and Israel: Will the Real Universal Design Please Stand Up?
}

\author{
Catherine Susan Fichten \\ Dawson College, Jewish General Hospital, McGill University \\ Tali Heiman \\ Open University of Israel
}

\author{
Alice Havel \\ Adaptech Research Network, Dawson College
}

Mary Jorgensen, Jillian Budd Adaptech Research Network

Laura King
Cégep André-Laurendeau, Adaptech Research Network

\begin{abstract}
We have examined the sustainability of providing services for students with disabilities in higher education in Canada and Israel. The two countries differ in their approaches: Israel subscribes to the accommodations model of service delivery; Canada, to the universal design approach. Case examples of services to students with disabilities in Canada and Israel are used to illustrate these approaches in a descriptive, illustrative study of 214 students with disabilities in Israel and the 127 in Canada who self-reported a disability and who had or had not registered for disability-related services from their school. Contrary to expectation, the Canadian sample (universal design) had a larger proportion of students with disabilities registered for disability-related services than the Israeli sample (accommodations model).
\end{abstract}


Moreover, in Israel, disability-related services were extended to more diverse populations. While the universal design model has the potential to enhance sustainability of disability-related services in higher education, this has yet to be demonstrated empirically. Recommendations for increasing sustainability through universal design are made.

Canada and Israel differ in the approaches taken to address disability and discrimination in post-secondary education. There are two dominant service delivery models for how students with disabilities (e.g., physical, sensory, and specific learning disabilities) can effectively participate in college and university education: the accommodation model popular in Israel and several European countries - and the universal design framework (UD) that is rapidly gaining popularity in Canada and the United States. Here we compare the two views, examine their impact on sustainability, and illustrate how the two models are used in Canada and Israel.

\section{Principles and Frameworks}

\section{Accommodation Model}

In many countries, including Israel, colleges and universities typically use accommodations to assist students with disabilities (Sachs \& Schreuer, 2011). This practice reflects the "medical model" in which the emphasis is on managing the student's disability (Shakespeare, 2010). Campus disability service providers arrange for accommodations for each student based on diagnosis and needs, with the goal of "leveling the playing field." After receiving appropriate documentation, the disability service provider meets with the student to develop an accommodation plan that enables the student to participate fully in academic and campus life.

Academic accommodations can include note takers; recording of lectures; captioning, Communication Access Realtime Translation (CART), infrared or FM listening systems, and language interpreting for students who are Deaf and hard of hearing; class relocations; ergonomic back support and priority seating in class; specialized wheelchair-accessible tables and workstations; reduced course load while maintaining full-time status; assignment substitutions; field or practicum placement supports; specialized learning skills services; and alternate format materials. In addition, a variety of testing accommodations can be offered, including: scribes, extended time, short supervised breaks, a distraction-reduced environment, and the use of assistive technologies such as computers (Barazandeh, 2005; National Educational Association of Disabled Students, 2012).

Until relatively recently, North American schools, along with most European and Israeli schools, followed the accommodations model. Given the large numbers of students with disabilities enrolled in colleges and universities, the accommodation approach becomes unsustainable as it requires, "retrofitting, repeated each semester, for each course, for each individual student ... with the number of users exploding in an unprecedented way" (McGill Office for Students with Disabilities, 2015). 


\section{Universal Design (UD) Approach}

An alternate view of "leveling the playing field" is based on UD, a concept which originated in architecture. It offers a method for designing structures that work for everyone because the physical and sensory needs of all potential users are taken into account during the planning stages. Seven principles governing the design of universally accessible products and environments were proposed by Story, Mueller, and Mace (1998). These principles were subsequently adapted to post-secondary education and several frameworks for the application of UD to instruction have emerged (see Burgstahler, 2015b).

UD principles follow the "social model of disability," in which the focus is on making changes to the environment, not the person (Barnes, 2009). The UD approach avoids costly retrofits by responding to the potential diversity of users from the inception (e.g., make curb-cuts as the sidewalk is being built rather than after it is completed). The goal of UD is to create more inclusive environments for all learners, eliminating the need for expensive accommodations. Two complementary UD theoretical formulations dominate: Universal Design of Instruction (McGuire, Scott, \& Shaw, 2003; Scott, Loewen, Funckes, \& Kroeger, 2003) and Universal Design for Learning (CAST, 2011).

Universal Design of Instruction (UDI). McGuire et al. (2003) and Scott et al. (2003) added two principles to the original seven proposed by Story et al. (1998) and reformulated the UDI concepts to apply to post-secondary teaching. The objective of UDI is to design instruction to be accessible to all students from the outset. Table 1 shows the nine principles as applicable to post-secondary education.

Universal Design of Learning (UDL). UDL is based on the work of CAST (2011) and focuses on flexibility in curriculum design (Alchin, 2015; Gravel, Edwards, Buttimer, \& Rose, 2015). It proposes that three core principles need to be followed for diverse learners to benefit from instruction. Instructors need to provide multiple pathways for students (a) to learn, (b) to interact with peers and faculty, and (c) to demonstrate what they have learned (Black, Weinberg, \& Brodwin, 2015). The three principles of UDL (i.e., Multiple Means of Engagement, Multiple Means of Representation, Multiple Means of Action and Expression) along with examples of how these can be applied to post-secondary teaching, are presented in Table 2.

It should be noted that following the principles of UDL addresses the needs of diverse learners, but it does not ensure accessibility to all learners (Thomson, Fichten, Budd, Havel, \& Asuncion, 2015). For example, watching a video to illustrate a point in the textbook provides for Multiple Means of Representation, but may not provide full access for a student with a visual impairment, who might benefit from having an audio description, or for a student with a hearing impairment, who might need to have the video captioned. Thus, UDL alone cannot eliminate the need for all accommodations, but combining UDI and UDL can abolish the need for many commonplace accommodations such as making alternate format materials on site or paying note takers. 


\section{Table 1}

\section{The Nine Principles of Universal Design of Instruction ${ }^{1}$}

\begin{tabular}{l} 
Principles and definitions \\
\hline 1. Equitable Use \\
The course does not penalize any group of \\
students \\
\hline 2. Flexibility in Use \\
Instruction is designed to accommodate a \\
wide range of individual abilities and take \\
account of differences among students.
\end{tabular}
3. Simple and Intuitive
Instructions are easy to understand, and tools are simple to use.

4. Perceptible Information

Essential information is conveyed effectively, so as to be understood by all the students independently of their sensory skills.
Sample recommendations for adapting courses to a more diverse student population

- Use different methods of delivering content (lectures, peer teaching, etc.).

- Prior to each class, provide course notes online.

- Give students several evaluation options (term work, oral presentations, portfolios, etc.).

- Enhance instruction via visual representations such as diagrams.

- Choose textbooks that include a summary and key words for each chapter.

- For slide presentations, use a large font and good colour contrast.

- Supply all course visual and sound content (e.g., hard copies of slide shows in which image content is described).

- Ensure that videos are captioned.

5. Tolerance for Error

Possible variations in student learning rates are anticipated; risks of error due to accident are minimized.

- Ensure that online examinations allow students who accidentally press the wrong key to go back and correct their mistake.

- Put practice exams online.
- Allow students to do written work in class on computer, so they can modify or revise without constantly having to erase and rewrite their texts.

- Let students submit assignments by e-mail.

- Opt for several short exams rather than one long one.

The course minimizes the need for physical effort that is not essential to instructional objectives.

7. Size and Space for Approach and Use Space is organized so that all students, regardless of their size, posture or mobility, have enough room to move around.

8. A Community of Learners

The environment promotes interaction and communication between students and teachers.

\begin{tabular}{ll}
\hline 9. Instructional Climate & Maintain high expectations of students while \\
$\begin{array}{l}\text { The environment is conducive to learning } \\
\text { and the inclusion of all students. }\end{array}$ & $\begin{array}{l}\text { remaining open to any discussion of special needs } \\
\text { and promoting an atmosphere conducive to } \\
\text { learning and communication. }\end{array}$ \\
\hline
\end{tabular}

- Provide enough space for sign-language interpreters, guide dogs and various technologies.

- Ensure that students' visual field is unobstructed during demonstrations.

- Use various means to encourage the inclusion of all students in discussion groups (classroom teamwork, discussion forums, Facebook, etc.).

\footnotetext{
${ }^{1}$ Adapted from Barile, Nguyen, Havel, \& Fichten (2012).
} 
Table 2

The Three Principles of Universal Design For Learning (UDL)

\begin{tabular}{ll}
\hline \multicolumn{1}{c}{ Principles } & \multicolumn{1}{c}{ Descriptions } \\
\hline Multiple Means of Engagement & $\begin{array}{l}\text { Instructors offer multiple pathways to engage students in } \\
\text { the course material (e.g., wikis, group chats, online mind } \\
\text { mapping) }\end{array}$ \\
Multiple Means of Representation & $\begin{array}{l}\text { Course content offered in a multitude of formats (e.g., } \\
\text { PowerPoint, video, podcast, images) }\end{array}$ \\
Multiple Means of Action and Expression & $\begin{array}{l}\text { Instructors offer multiple methods of expression and } \\
\text { evaluation of students' knowledge of course content } \\
\text { (e.g., participation in discussion forum, online multiple- } \\
\text { choice quiz, virtual group project) }\end{array}$ \\
\hline
\end{tabular}

\section{Sustainability}

While there are many paths to sustainability in higher education, our concern is with the role of universal design in ensuring access for students with disabilities. With the large numbers of post-secondary students with disabilities, exclusive use of the accommodation model will soon no longer be affordable in terms of finances, human resources, or space. Some institutions, both Canadian and American, have already made public their commitment to UD and its obvious relationship to sustainability (Dawson College AccessAbility Centre, n.d.; McGill Office for Students with Disabilities, 2015).

Incorporating seamless access into classrooms and curriculum will increase sustainability, as accommodations ... are individual and consumable. For example, individual accommodations must be determined for each student, each class, each semester. However, when the curriculum is designed to be inclusive, the need to facilitate individual accommodations each semester is reduced. (The University of Arizona Disability Resources, 2015)

\section{Canada vs. Israel}

Both countries have a large number of students with disabilities. Although Israeli statistics are unavailable, in Canada the figure is over 11\% (Association of Canadian Community Colleges, 2014; Association of Universities and Colleges of Canada, 2014; Ministry of Training, Colleges \& Universities, 2012). Providing individualized services to all students - the current custom in Israel and the custom, until recently, in Canadawill soon no longer be affordable in terms of funds, space, and personnel (Beck, del Castillo, Fovet, Mole, \& Noga, 2013).

Israel and Canada are dissimilar in many ways that affect education, including language and alphabet. In addition, the post-secondary education systems differ. For example, in some parts of Canada (e.g., in Quebec, Canada's second largest province) students register in junior college upon graduating from high school after 11 years of schooling. Students planning to obtain a bachelor's degree complete two compulsory years of junior college before enrolling in a three-year university bachelor's program. If they do not plan to pursue 
a bachelor's degree, Canadian junior college students can opt to enrol in three-year career or technical programs (e.g., nursing, interior design, business administration).

In many parts of Canada, students typically enrol in a three-year bachelor's program upon graduating from high school after 12 years of schooling. Once they graduate from high school, Israeli students typically enlist in the army. Once they leave the army, they also enrol in a three-year bachelor's program. Canadian students do not routinely enrol in the army. Moreover, the sample of Israeli students in the study described below attended an open university (i.e., where all those who wish to enrol can do so for a single course or for a full program of study leading toward a bachelor's degree). The school attended by the Israeli students in our study offers both distance education and blended learning (partly face-to-face, partly online).

Students with disabilities. What the two countries do have in common are similar proportions of individuals with disabilities (14\%-16\%: World Health Organization, 2011, Technical Appendix A, p. 271) and a commitment to the success of post-secondary students with disabilities (The Open University of Israel, n.d.; Dawson College Student Accessibility, 2015). For example, a major Israeli university

believes that all of its students and staff should be entitled to equal access to university facilities, resources and activities, regardless of physical, sensory or mental limitations and disabilities. TAU strives to provide a safe and welcoming environment for people with disabilities and makes accessibility a priority in designing and upgrading the TAU campus. (Tel Aviv University, n.d.)

Other Israeli universities have similar statements related to disabilities on their web site (e.g., The Hebrew University of Jerusalem, 2016). One realm in which countries often differ concerns students with specific learning disabilities. "For example, in the USA and Canada they use the term 'intellectual disability' for what we in the UK would describe as a 'learning disability" (Foundation for People with Learning Disabilities, n.d., para. 4). Here, too, however, Israeli and North American views are very similar, and do not include intellectual disability (Al-Yagon et al., 2013; Heiman, 2006).

However, given the clear distinction between the UD and accommodation models, we would expect to find differences between Canada and Israel in how the postsecondary institutions respond to students with disabilities. In particular, we would expect that in Canada, where the UD model is becoming popular (Beck et al., 2013; Konstantinopoulos, Lister, MacDonald, \& Wileman, 2015; McGill Office for Students with Disabilities, 2015), a smaller proportion of post-secondary students with disabilities would find it necessary to register with their school's disability services office to receive accommodations, such as note-takers, than in Israel.

\section{The Present Investigation}

Here our goal is to examine similarities and differences in the percentage of students who registered for disability-related accommodations from their school in Israel and Canada. We examine this by looking at two concrete examples: students with disabilities in Canada and Israel. The Canadian sample was obtained from a Quebec junior college where students were enrolled in diploma (associate's degree) programs; while in Israel, 
students were attending an open university with both distance and blended approaches, with most being enrolled in a bachelor's program. Thus, while the samples are very different, findings on students with disabilities are pertinent to an examination of accommodation vs. UD approaches. In particular, we made the following hypotheses:

1. Given the military service requirement in Israel, we expected a larger proportion of Israeli students to be veterans with disabilities such as mobility impairments, and chronic physical and mental health issues, such as post-traumatic stress disorders.

2. Given the increased implementation of the UD model in Canada, and in the college studied in particular (Dawson College AccessAbility Centre, n.d.) and the continued use of the accommodation model in Israel, we hypothesized that a greater percentage of students with disabilities would register for disabilityrelated services in Israel than Canada.

\section{Method}

\section{Participants}

The 127 students with disabilities ( 75 females, 50 males, 2 did not indicate) in Canada were all enrolled in a junior college. They were part of a random sample of 812 students (482 females, 325 males, 5 did not indicate gender) over age 18 who had been enrolled in 27 compulsory English literature classes in a large Montreal-area junior college. All had completed at least seven first-semester courses. In Israel, the 214 students with disabilities (111 females, 103 males, 1 did not indicate gender) were part of a random sample of 973 students (562 females, 411 males) who had successfully completed at least four academic courses in an open university featuring both blended and distance education courses.

\section{Procedure}

The research protocol was approved by Dawson College's Research Ethics Board and by the Ethics Committee of the Open University of Israel. The study was conducted in the fall of 2014. In Canada, measures were administered in conventional paper and pencil format in 27 compulsory English classes. In Israel, measures were administered via a Google Docs questionnaire submitted to a random sample of 2,650 students who successfully finished at least four academic courses in an open university featuring both blended and distance education courses.

Questions. All students were asked about gender, age, and program of studies pursued (in Canada: pre-university program, career or technical program; in Israel: bachelor's degree, master's degree, teacher's certification, other). Canadian participants were informed that they could obtain the questions in large print or in Microsoft Word format; none asked for this. All participants were asked, "Are you registered with your school to receive accommodations related to a disability? Yes/No"; and they were also asked to self-identify as many of the listed disabilities as applied to them. (Questions are available in the Appendix.) 


\section{Results}

Data were analyzed using descriptive statistics, t-tests, and chi-squares. Response rates were over $98 \%$ in Canada and over $40 \%$ in Israel.

\section{Age and Gender}

As expected, given the differences between Israel and Canada and between junior colleges and open universities, the two samples differed in age, with Canadian students being significantly younger $($ mean $=19.50$ years, range $=18-45$ years $)$ than Israeli students (mean = 29.56 years, range $17-42$ years $), t(1771)=52.17, p<.001$. There was no significant difference between the Canadian and Israeli samples on gender, $\chi^{2}(1,1780)=.70, p=.401$.

\section{Disability}

A significantly larger proportion of students in Israel indicated that they had a disability, $\chi^{2}(1,1785)=11.56, p<.001: 16 \%$ of the Canadian sample $(127$ of 812 participants) and $22 \%$ of the Israeli sample (214 of 973 participants) indicated that they had at least one of the seven disabilities or impairments we listed. Perhaps more interesting was the nature of students' disabilities. In Hypothesis 1 we stated that we expected that Israeli students, because of army service, etc., would have more mobility, sensory, health, and mental health problems. However, this was not the case. Instead, as shown in Table 3, Israeli students almost exclusively identified as having learning disabilities and/or attention deficit hyperactivity disorder (LD/ADHD). Canadian students were also most likely to self-report LD/ADHD. They were, however, more likely than Israeli students to report mental illness and chronic health problems.

Given the preponderance of students with LD/ADHD, as shown in Table 3, and the substantial differences in the number of students with other disabilities, to keep students' disabilities consistent, subsequent analyses were carried out on students with LD/ADHD only.

Table 3

Disability Characteristics of Students in Canada and Israel

\begin{tabular}{lcccc}
\hline \multirow{2}{*}{ Disability or Impairment } & \multicolumn{2}{c}{ Canada } & \multicolumn{2}{c}{ Israel } \\
\cline { 2 - 5 } & $\boldsymbol{n}=\mathbf{1 2 7}$ & $\%$ & $\boldsymbol{n = 2 1 4}$ & $\%$ \\
\hline Learning disability and/or ADHD & 61 & $48 \%$ & 179 & $84 \%$ \\
Mental illness & 46 & $36 \%$ & 1 & $0 \%$ \\
Chronic health problem (e.g., diabetes) & 25 & $20 \%$ & 3 & $1 \%$ \\
Deaf or hard of hearing & 6 & $5 \%$ & 12 & $6 \%$ \\
Blindness or low vision & 3 & $2 \%$ & 8 & $4 \%$ \\
Other & 3 & $2 \%$ & 3 & $1 \%$ \\
Mobility impairment & 1 & $1 \%$ & 6 & $3 \%$ \\
Autism spectrum disorder & 1 & $1 \%$ & 1 & $0 \%$ \\
\hline
\end{tabular}

${ }^{1}$ Participants were allowed to check as many as applied to them. 


\section{Registration for Disability-Related Services}

Given the prevalence of the UD model in Canada and the accommodation model in Israel, we expected that more students with LD/ADHD would have registered for disability-related services in Israel than in Canada (Hypothesis 2). However, as seen in Table 4, a higher proportion of students with $\mathrm{LD} / \mathrm{ADHD}$ in Canada (56\%) registered for disability-related services than did so in Israel $(36 \%), \chi^{2}(1,237)=7.01, p=.008$.

Table 4

\section{Country and Registration for Disability-Related Services} by Students with LD/ADHD

\begin{tabular}{lcc}
\hline Registration Status & Canada & Israel \\
\hline Registered for disability-related services & 34 & 64 \\
Not registered for services & 27 & 112 \\
\hline
\end{tabular}

\section{Discussion}

The findings of our volunteer convenience samples ${ }^{1}$ show that a very large number of students self-identified as having a disability or impairment, both in Canada (16\%) and Israel $(24 \%)$. Nevertheless, these percentages are in line with North American studies (Ministry of Training, Colleges \& Universities, 2012; Snyder \& Dillow, 2012), and, in practical terms, suggest that more than 2,000 of the Canadian college's 12,500 students and more than 11,000 of the Israeli university's 48,000 students have a disability that could affect their grades and likelihood of graduation. These are enormous numbers, and providing individual accommodations to these students is likely to be expensive and burdensome for the schools. Thus, a universal design (UD) approach is very likely to be beneficial.

\section{Learning Disability / Attention Deficit Hyperactivity Disorder}

The most common disorder self-identified by both Canadian and Israeli samples was a specific learning disability with or without attention deficit hyperactivity disorder (LD/ADHD). Such students often have a difficult time succeeding in post-secondary education (Jorgensen, Fichten, \& Havel, 2009; Wagner, Newman, Cameto, Garza, \& Levine, 2005; Weyandt et al., 2013). Yet, in our study close to $50 \%$ of them had not registered for disability-related services from their school. The large numbers of students who self-report LD/ADHD and do not register for disability-related services, added to the large numbers who only learn that they have LD or ADHD when they run into academic problems as reading loads get heavy (Harrison, Larochette, \& Nichols, 2007), also point toward the importance of a UD approach. For example, if textbooks are available in both print and digital formats, students unaware of their LD can listen to their textbooks rather than reading these in the conventional way.

\footnotetext{
${ }^{1}$ Non-probability samples for which participants are selected because they are available to participate in the research study; can cause problems for the generalization of the results.
} 
Although we had expected a larger portion of students with mobility impairments and chronic health- and mental health-related disabilities in the Israeli sample, this hypothesis was not confirmed. This may be due to how disability categories are defined in the two countries, to the mode of instruction in face-to-face and blended learning environments, as well as to differences in how students self-identify a disability.

Indeed, what is of interest is the large number of students with mental health-related disabilities in the Canadian sample. We can only speculate about the reason for the Canada-Israel discrepancy. Perhaps Israeli students with mental health-related disabilities simply do not consider themselves to have a disability. Also, students with mental health-related disabilities may experience different levels of stigma in the two countries. Alternately, students who have a disability that is comorbid with LD/ADHD, such as a mental health-related disability, may choose not to disclose this because of the stigma attached to it. It might also be that students in an open university experience less academic anxiety than Canadian students who are vying for admission to competitive bachelor's programs. For Canadian students, a level playing field may be imperative and, thus, they might be willing, in spite of fear of social stigma, to identify themselves more readily in order to obtain accommodations. Yet, our data (Jorgensen, Budd, Fichten, Nguyen, \& Havel, 2016) suggest that this group of students has the worst academic outcomes among students with disabilities. The literature (e.g., St-Onge, Tremblay, \& Garneau, 2009) also indicates that a variety of accommodations are needed for these students as well. Since these students tend not to register for disability-related services, a UD approach will serve them well, too.

\section{Registration for Disability-Related Services}

That a much larger proportion of Israeli (64\%) than Canadian (44\%) students had not registered for disability-related services suggests that UD is not yet alive and well in Canada - at least in the college studied. Clearly, in order to promote UD in higher education in Canada, more work needs to be done.

Alternately, it is also possible that because the Israeli school in this investigation was an open university, with both distance education and blended courses, fewer accommodations are needed by students with disabilities than in schools where students must attend in person, as many accommodations, such as note takers and wheelchairaccessible tables are unnecessary in distance education. For example, as noted on the web site of a Canadian open university that offers both distance and blended courses, accommodations are most likely to be needed only for alternate formats and methods of communication, and for access to adaptive technology and materials in the examination environment (Thompson Rivers University, n.d.).

But why the high proportion of non-registered students in Israel, which favours the accommodation model? While this may be due to sampling issues, since students attended an open university and since the response rate was only $40 \%$, it is also possible that the nature of the courses and the instructional techniques utilized in the university are already UD based, without the school or the instructors identifying this as such. For example, in Israel, students at the Open University can register in blended and distance education courses and their progress is measured not in semesters or years, but in number 
of completed courses. In the United Kingdom, the Open University is developing its social learning platform, where a key objective is:

Improving the flexibility and availability of courses. For example, introducing longer windows for courses that will allow learners more opportunities to join at a time that is convenient to them, enabling a more flexible course schedule and greater support for learning with a cohort and in groups. (The Open University, 2015)

If open universities are aware of the profile of the students they attract, they may be cognizant of the diverse needs of their students, which they address in the early stages of course design. Similarly, Canada's largest open distance education university delivers many courses through a digital content management learning system that can be accessed on the internet. Its web site states that the school is committed to the adoption of universal design principles (Athabasca University, 2014).

\section{Limitations and Future Research}

We need to note that the empirical data presented here constitute two case studies and not a true comparison of the Israeli and Canadian higher education systems. First, while the Canadian site certainly knows about the model, there are no available data on how well this was implemented. Our samples came from very different post-secondary institutions: different instructional formats, large age difference in the samples, questions administered via a paper-and-pencil questionnaire vs. an online questionnaire, different response rates. Moreover, disability was self-defined by the students. While self-reporting is not always reliable, this was the most appropriate for data collection in our investigation. It was not possible to obtain formal diagnoses, especially for LD/ADHD, which in any case is subject to substantial inconsistency, even within Canada. (Harrison \& Holmes, 2012). In addition, we did not distinguish between students with specific learning disabilities and those with attention deficit hyperactivity disorder. Even though there is substantial comorbidity between these disorders, it is essential to study these samples separately (Budd, Fichten, Jorgensen, Havel, \& Flanagan, 2016). In future investigations, research should be carried out at several comparable schools, perhaps in the context of institutional research in which results are not affected by volunteer or self-selection effects.

\section{Who is Adopting the UD Model?}

In Israel, following an accommodation model, students are entitled to accommodations under certain circumstances, whether they have a disability or not. These include reasons other than a disability — such as being an immigrant, a member of a minority group, pregnancy, being in the army during the exams, and medical documentation related to disability due to an accident. Perhaps Canada is not adhering to the social model of UD to the extent we had assumed; and perhaps Israel, which follows a proactive model of accommodations, is more UD-oriented than was anticipated.

So which country, then, is more likely to follow a UD model? In Canada, where there is a strong push toward universal design (Beck et al., 2013; Konstantinopoulos et al., 2015; McGill Office for Students with Disabilities, 2015), there continues to be a strong reliance on accommodations and, thus, larger percentages of students with 
disabilities than in Israel are enrolled to receive services. Many Canadian students without disabilities who are in need of accommodations cannot access these because they cannot provide the medical documentation that most Canadian schools still require to accompany any request for accommodations.

\title{
Recommendations for Sustainable UD Practices in Post-secondary Education-Extending the Findings
}

\begin{abstract}
What if there were a paradigm for higher education that simultaneously addressed issues of diversity, equality, accessibility, social integration, and community? What if this approach went beyond the design of more inclusive instruction to provide guidance for making physical spaces, student services, and technology more welcoming to, accessible to, and usable by everyone on campus? The application of UD in higher education can do all of this and more. (Burgstahler, 2015a, p. 3)
\end{abstract}

\section{Help Faculty Implement UD}

Although numerous resources are readily available to assist instructors in the implementation of UD into their course design and teaching practice (Burgstahler, 2015b; CAST, 2011), UD has yet to be embraced by large numbers of faculty in colleges and universities. One reason may be that many instructors view the responsibility to accommodate students with disabilities in higher education as the purview of disability resource centres. As well, while administrators may be aware of the long-term sustainability benefits of UD, instructors quickly realize that the initial stages of implementing UD are time consuming. What can administrators do to promote UD in their institutions? Along with developing policies that clearly reflect diversity as an institutional value, administrators need to ensure that instructors are provided with professional development opportunities to further their understanding of UD and that they provide instructors with the time to initially incorporate UD into their course design. This may take time, since substantial extra effort is required by instructors teaching multiple different courses. Once the initial effort is made by faculty, maintaining the UD components may become routine, improving or moving toward sustainability.

\section{Set Shorter Exams}

The most frequently requested accommodation among students with learning disabilities in post-secondary settings is extended test time (Ofiesh, Hughes, \& Scott, 2004). With the increasing numbers of students registered for this accommodation, at peak periods such as mid-terms disability resource centres are hard pressed to locate sufficient physical space, let alone hire the necessary clerical staff and invigilators to meet the demand. If instructors were to prepare an exam that could be completed by the vast majority of students within the time allotted for it (i.e., non-speeded test), most students with learning disabilities would be able to remain with their peers during testing. This is an example of a UD approach. Students who are second language learners or who process information more cautiously could also benefit. Giving students shorter exams would result in responding to greater learner variability in a more sustainable way, i.e., 
without the additional costs or resources of space and personnel related to having the disability service office provide extended time accommodation.

\section{Provide Accessible Digital Copies of Course Materials}

When instructors provide accessible digital equivalents of all their hardcopy handouts and select textbooks that are available in both digital and print formats, disability resource centres no longer need to scan text. Obviating this labour-intensive service provides significant sustainability benefits.

Students with print impairments, including those with visual impairments and learning disabilities, can then enlarge the print or use text-to-speech software without the usual lengthy delay of submitting a request for alternative format. The availability of digital material can also be important for students without disabilities (Muller \& Tschantz, 2003). For example, students can facilitate their learning by highlighting words, enlarging text, increasing the volume of audio material, using links to look up unfamiliar words, etc. Specifically, those learning a new language may profit from being able both to see and to hear text passages.

\section{Make UD Tool Kits Available}

The implementation of UD is proactive, for it builds in accommodations that provide immediate accessibility for all students, regardless of their diverse learning needs. In spite of differences found in our two samples, the UD model should be applicable to students with and without disabilities in both Canada and Israel. One strategy to respond to this challenge is to encourage higher education institutions in both countries to support their instructors in the preparation of UD tool kits (e.g., Thomson, 2015; UQAM, CRISPESH, Collège Montmorency, \& CVM, 2015). Such tool kits can contain examples of exemplary practice, guidelines to follow, technologies, and communities of practice. Like our other recommendations, a well-publicized UD tool kit enhances sustainability by reducing the need for accommodations for students with disabilities.

\section{UD Resources}

In addition to the excellent print resource Burgstahler's (2015b), a variety of practical UD techniques in higher education are available online:

- Burgstahler, S. (2012). Universal design in education: Principles and applications. http://www.washington.edu/doit/universal-design-education-principles-andapplications

- Ryerson University Learning and Teaching Office. (2015). Recommendations for practice at Ryerson. Retrieved from http://www.ryerson.ca/lt/resources /supporting_students/universal_design/recommendations.html\#Syllabus

- Student Accessibility Centre of Dawson College. (n.d.). Universal design for learning resources. Retrieved from http://www.dawsoncollege.qc.ca/studentaccessibility/faculty/universal-design-for-learning-resources/ 


\section{References}

Al-Yagon, M., Cavendish, W., Cornoldi, C., Fawcett, A. J., Grünke, M., Hung, L.-Y., ... Vio, C. (2013). The proposed changes for DSM-5 for SLD and ADHD: International perspectivesAustralia, Germany, Greece, India, Israel, Italy, Spain, Taiwan, United Kingdom, and United States. Journal of Learning Disabilities, 46(1), 58-72. doi:10.1177/0022219412464353

Alchin, G. (2015, May). An introduction to Universal Design for Learning v2.0 (Presenter notes). Paper presented at the Rural and Remote Conference 2016, Bathurst, NSW, Australia. Retrieved from http://www.rde.nsw.edu.au/randrconf2016/files/2016/05/UDLintro-2m7agg5.pdf

Association of Canadian Community Colleges. (2014). The Association of Canadian Community CollegesAnnual report 2013-14. Ottawa, ON. Retrieved from http://www.collegesinstitutes.ca/wpcontent/uploads/2014/05/accc_ENG_annual_report_2013-14_may25.pdf

Association of Universities and Colleges of Canada. (2014). Canadian universities. Retrieved from http://www.aucc.ca/canadian-universities/

Athabasca University. (2014, April 30). Access to students with disability policy: Accessibility. Retrieved from http://asd.athabascau.ca/policy/accessibility.php

Barazandeh, G. (2005). Attitudes toward disabilities and reasonable accommodations at the university. The UCI Undergraduate Research Journal, 8, 1-12. Retrieved from http://www.urop.uci.edu/journal/journal05/01_barazandeh.pdf

Barile, M., Nguyen, M. N., Havel, A., \& Fichten, C. S. (2012). Universal design of instruction: A winwin situation! Pédagogie collégiale, 25(4), 20-22. Retrieved from http://aqpc.qc.ca /sites/default/files/revue/BarileNguyenHavelFichten-25-4A-2012.pdf

Barnes, C. (2009, November). Understanding the social model of disability (Presentation notes). Paper presented at the conference, "Från forskningsobjekt till medaktör," Stockholm University, Stockholm, Sweden. Retrieved from http://www.hso.se/Global/Projekt/Fr\%C3\%A5n\%20 forskningsobjekt/Forskning/Anteckningar\%20Colin\%20Barnes\%20091118.pdf

Beck, T., del Castillo, P. D., Fovet, F., Mole, H., \& Noga, B. (2013). Applying universal design to disability service provision: Outcome analysis of a universal design (UD) audit. Journal of Postsecondary Education and Disability, 26(4), 209-222. Retrieved from http://files.eric.ed.gov/fulltext/EJ1040544.pdf

Black, R. D., Weinberg, L. A., \& Brodwin, M. G. (2015). Universal design for learning and instruction: Perspectives of students with disabilities in higher education. Exceptionality Education International, 25(2), 1-26. Retrieved from http://ir.lib.uwo.ca/cgi/viewcontent.cgi ?article $=1131 \&$ context $=$ eei

Budd, J., Fichten, C. S., Jorgensen, M., Havel, A., \& Flanagan, T. (2016). College and university students with specific learning disabilities and with attention deficit hyperactivity disorder should not be considered as a unified group for research or practice. Journal of Education and Training Studies (JETS), 4(4), 206-216. doi:10.11114/jets.v4i4.1255

Burgstahler, S. E. (2015a). Universal design in higher education. In S. E. Burgstahler (Ed.), Universal design in higher education: From principles to practice (2nd ed., pp. 3-28). Boston, MA: Harvard Education Press.

Burgstahler, S. E. (2015b). Universal design of instruction: From principles to practice. In S. E. Burgstahler (Ed.), Universal design in higher education: From principles to practice (2nd ed., pp. 31-64). Boston, MA: Harvard Education Press.

CAST. (2011). Universal Design for Learning guidelines version 2.0. Wakefield, MA: Author. Retrieved from http://www.udlcenter.org/aboutudl/udlguidelines 
Dawson College AccessAbility Centre (n.d.). The Student AccessAbility Centre and universal design. Retrieved from http://www.dawsoncollege.qc.ca/student-accessibility/faculty/universal-designfor-learning-resources/

Dawson College Student Accessibility. (2015). Student accessibility [Web page]. Retrieved from http://www.dawsoncollege.qc.ca/student-accessibility/

Foundation for People with Learning Disabilities. (n.d.). What does the term 'learning disability' mean? Retrieved from http://www.learningdisabilities.org.uk/help-information/about-learningdisabilities/definition-learning-disability/

Gravel, J. W., Edwards, L. A., Buttimer, C. J., \& Rose, D. H. (2015). Universal design for learning in postsecondary education: Reflections on principles and their application. In S. E. Burgstahler (Ed.), Universal design in higher education: From principles to practice (2nd ed., pp. 81100). Boston, MA: Harvard Education Press.

Harrison, A. G., \& Holmes, A. (2012). Easier said than done: Operationalizing the diagnosis of learning disability for use at the postsecondary level in Canada. Canadian Journal of School Psychology, 27, 12-34. doi:10.1177/0829573512437021

Harrison, A. G., Larochette, A.-C., \& Nichols, E. (2007). Students with learning disabilities in postsecondary education: Selected initial characteristics. Exceptionality Education Canada, $17(2), 135-154$.

Heiman, T. (2006). Assessing learning style among students with LD at a distance-learning university. Learning Disability Quarterly, 29, 55-63.

Jorgensen, M., Budd, J., Fichten, C. S., Nguyen, M. N., \& Havel, A. (2016). Graduation and grades of college students with learning or mental health related disabilities. Manuscript submitted for publication.

Jorgensen, S., Fichten, C. S., \& Havel, A. (2009). Academic success of graduates with and without disabilities-A comparative study of university entrance scores [Special issue]. Pédagogie collégiale, 22(5), 26-29. Retrieved from http://www.adaptech.org/sites/default/files /AbAcademicSuccessOfGraduates.pdf

Konstantinopoulos, E., Lister, C., MacDonald, C., \& Wileman, S. (2015, October). Walking the walk, not just talking the talk: Implementing UD in the AccessAbility Centre. Paper presentation at Dawson Pedagogical Day, Montreal, Quebec.

McGill Office for Students with Disabilities. (2015). Universal design [Web page]. Retrieved from https://www.mcgill.ca/osd/facultyinfo/universal-design

McGuire, J. M., Scott, S. S., \& Shaw, S. F. (2003). Universal design for instruction: The paradigm, its principles, and products for enhancing instructional access. Journal of Postsecondary Education and Disability, 17(1), 10-20. Retrieved from http://files.eric.ed.gov /fulltext/EJ875999.pdf

Ministry of Training, Colleges and Universities - Ontario, Postsecondary Education Division. (2012, May). Update On Students With Disabilities. PowerPoint presentation at the University of Michigan. Retrieved from http://tinyurl.com/hf6bkjr

Muller, E., \& Tschantz, J. (2003, April). Universal design for learning: Four state initiatives. Alexandria, VA: Project Forum, National Association of State Directors of Special Education. Retrieved from http://www.nasdse.org/Projects/ProjectForum/tabid/415/Default.aspx

National Educational Association of Disabled Students. (2012). Enhancing accessibility in postsecondary education institutions: A guide for disability service providers. Ottawa, ON: Author. Retrieved from http://www.neads.ca/en/norc/eag 
Ofiesh, N. S., Hughes, C., \& Scott, S. S. (2004). Extended test time and postsecondary students with learning disabilities: A model for decision making. Learning Disabilities Research and Practice, 19(1), 57-70. doi:10.1111/j.1540-5826.2004.00090.x

Sachs, D., \& Schreuer, N. (2011). Inclusion of students with disabilities in higher education: Performance and participation in student's experiences. Disability Studies Quarterly, 31(2). Retrieved from http://dsq-sds.org/article/view/1593/1561

Scott, S. S., Loewen, G., Funckes, C., \& Kroeger, S. (2003). Implementing universal design in higher education: Moving beyond the built environment. Journal of Postsecondary Education and Disability, 16(2), 78-89. Retrieved from http://files.eric.ed.gov/fulltext/EJ875997.pdf

Shakespeare, T. (2010). The social model of disability. In L. J. Davis (Ed.), The disability studies reader (3rd ed., pp. 266-273). New York, NY: Routledge.

Snyder, T. D., \& Dillow, S. A. (2012). Digest of education statistics 2011[NCES 2012-001]. Washington, DC: National Center for Education Statistics, Institute of Education Sciences, U.S. Department of Education. Retrieved from http://nces.ed.gov/pubs2012/2012001.pdf

St-Onge, M., Tremblay, J., \& Garneau, D. (2009). L'offre de services pour les étudiants des cégeps ayant des problèmes de santé mentale ou un trouble mental: Rapport final de recherche présenté à la direction des affaires étudiantes universitaires et collégiales (DAEUC) du ministère de l'éducation, du loisir et du sport (MELS). Retrieved from http://www.education.gouv.qc.ca/fileadmin/contenu/documents_soutien/Ens_Sup/Collegial/I ntegration_etudiants/OffreServEtudCegepsSanteMentale_RapportSynt.pdf

Story, M. F., Mueller, J. L., \& Mace, R. L. (1998). The universal design file: Designing for people of all ages and abilities. Raleigh, NC: North Carolina State University. Retrieved from www.ncsu.edu/ncsu/design/cud/pubs_p/pudfiletoc.htm

Tel Aviv University. (n.d.). Accessibility at Tel Aviv University. Retrieved from https://english.tau.ac.il/accessibility

The Hebrew University of Jerusalem. (2016, March 27). Services for students with disabilities. Retrieved from https://overseas.huji.ac.il/?CategoryID $=958$

The Open University of Israel. (n.d.). Services to students at the Open University of Israel. Retrieved from http://www-e.openu.ac.il/dean/d07.html\#needsOpen University of Israel

The Open University. (2015, November 12). Fast-track growth for social learning as OU builds on success of FutureLearn. Retrieved from http://www3.open.ac.uk/media/fullstory.aspx?id=29550

The University of Arizona Disability Resources. (2015). Universal design for learning-UD. Retrieved from https://drc.arizona.edu/outreach-education/universal-design

Thompson Rivers University. (n.d.). Academic accommodation and services for students with disabilities. Retrieved from https://www.tru.ca/_shared/assets/Services_for_Students_with_Disabilities5619.pdf

Thomson, R. (2015). Universal design: Faculty research. McGill Office for Students with Disabilities. Retrieved from https://www.mcgill.ca/osd/facultyinfo/universal-design-faculty-research

Thomson, R., Fichten, C., Budd, J., Havel, A., \& Asuncion, J. (2015). Blending universal design, elearning, and information and communication technologies. In S. E. Burgstahler (Ed.), Universal Design in Higher Education: From Principles to Practice (2nd ed.), pp. 275-284. Boston, MA: Harvard Education Press.

UQAM, CRISPESH, Collége Montmorency, \& CVM. (2015). Les applications pédagogiques de la conception universelle de l'apprentissage. Retrieved from http://pcua.ca/

Wagner, M., Newman, L., Cameto, R., Garza, N., \& Levine, P. (2005). After high school: A first look at the postschool experiences of youth with disabilities: A report from the National Longitudinal 
Transition Study-2 (NLTS2): Executive Summary. Menlo Park, CA: SRI International. Retrieved from http://www.nlts2.org/reports/2005_04/nlts2_report_2005_04_execsum.pdf

Weyandt, L., DuPaul, G. J., Verdi, G., Rossi, J. S., Swentosky, A. J., Vilardo, B. S., ... Carson, K. S. (2013). The performance of college students with and without ADHD: Neuropsychological, academic, and psychosocial functioning. Journal of Psychopathology and Behavioral Assessment, 35(4), 421-435. doi:10.1007/s10862-013-9351-8

World Health Organization. (2011). World report on disability. Geneva, Switzerland: Author. Retrieved from http://www.who.int/disabilities/world_report/2011/report.pdf

\section{Appendix}

Please write your responses or fill in the circle with a pencil (like this: •).

Your gender: $\quad \bigcirc$ Female $\quad \bigcirc$ Male $\quad \bigcirc$ Other $\quad \bigcirc$ Prefer not to say

Your date of birth: Day: Month: Year:

How many college semesters have you completed?

Indicate which of the following apply to you (you can select more than one).

- Visual impairment (that is not adequately corrected by wearing glasses or contact lenses)

- Deaf or hard of hearing / hearing impairment

○ Learning disability and/or ADHD

○ Mobility impairment

○ Chronic medical / health problem (e.g., diabetes)

- Mental illness

○ Autism spectrum disorder

O Other (please specify)

- I do not have any of the above

Are you registered with your college to receive accommodations related to a disability? $\bigcirc$ Yes $\bigcirc$ No 